\title{
Cross Breeding between the Two Spider Mites Tetranychus urticae Koch and Tetranychus cucurbitacearum (Sayed) in Egypt
}

\author{
W. A. Attwa ${ }^{*}$; A. Y. M. El-Laithy ${ }^{* *}$; E. M. EL-Saiedy ${ }^{* *}$; \\ S. E Abd-Elrahaman ${ }^{* * *}$ and H. E. S. Sadek ${ }^{* *}$ \\ "Zoology Dept., Faculty of Science, AI-Azhar University \\ ${ }^{* *}$ Pests \& Plant Protection Dept., National Research Center \\ ${ }^{* * *}$ Plant Protection Research Institute, Agricultural Research Institute
}

\begin{abstract}
The green two-spotted spider mite Tetranychus urticae Koch and the red spider mite T. cucurbitacearum (Sayed) were subjected to study to shed lights on their identity based on state of reproductive compatibility. However cross breeding produced fertile and normal hybrids for F1 and F2 in relation to egg laying capacity and sex ratio of the offspring. Also inheritance of female offspring color was maternal.
\end{abstract}

Key Words: Tetranychus urticae, Green and red forms, Biology, cross breeding.

\section{INTRODUCTION}

The two spotted spider mite Tetranychus urticae Koch is world wide pest of several crops in open fields and green houses. Some studies concerned with identification of this mite and other related species in Egypt were carried out. Sayed (1946) described the common spider mite Eotetranychus cucurbitacearum stating to be dark to light red but sometimes greenish yellow. In 1976, Attiah restricted the name T. cucurbitacearum (Sayed) to the red mite and T. arabicus to the green one as two different species. He also mentioned that although some variations existed in the shape of the aedeagus within species yet, mating experiments showed that green mites from different localities in Egypt were compatible, and similar result was obtained with red mites.

However Zaher et al., (1981) and El-Enany et al., (1990) carried out successful cross breeding experiments between T. urticae Koch (green) and $T$. arabicus Attiah (green); the former $T$. urticae was from Germany for the first time and from Holland for the second experiment. Moreover, El-Enany et al., (1983) declared that the red spider mite $T$. cinnabarinus (Bois) did not interbreed with T. cucurbitacearum .

However, the green and red forms are still a debatable issue to be one or two species.

Gotoh and Tokioka (1996) found genetic compatibility among diapausing red, nondiapausing red and diapausing green forms of $T$. urticae. Also Hinomoto et al., (2001) stated that green and red forms belong to one species.

Some authors, who dealt with identification of Tetranychus urticae group using molecular taxonomy techniques, came to conclude that these are separate species. Sugasawa et al., (2002) mentioned that the gene flow between the forms of $T$. urticae appears to be extremely restricted indicating that a strong genetic differentiation is present between the two forms.

Generally this issue is thus debatable between acarologists; some have considered these two forms to be different species, semi-species or one species.

To determine whether the green form $T$. urticae and the red form T. cucurbitacearum are cospecific or not, it was felt necessary to investigate hybrid fertility, to clarify whether interbreeding between the two occurs and their hybrids can successfully produce fertile offspring.

\section{MATERIALS AND METHODS}

\section{Mite colony:}

Samples of the both $T$. urticae and $T$. cucurbitacearum were obtained from stock culture kept in Plant Protection Research Institute, Agricultural Research Center. These mites were then reared on potted bean plants Phaseolus vulgaris $\mathrm{L}$. in a growth chamber and inbreeding of each species was carried out for fifteen generations in the laboratory to assure homozygosity.

Mites. Each spider mite, the green T. urticae and the red $T$. cucurbitacearum were thoroughly identified. They are very near in their morphology but characterized by the following:

a) T. urticae female with basic color green; male with aedeagal knob about one fourth as long as dorsal margin of shaft; anterior projection of knob rounded while posterior projection acute.

b) T. cucurbitacearum female with basic color red; male with aedeagal knob about one fifth as long as dorsal shaft margin; posterior angulation of knob acute while anterior angulation acute or else 
very slightly rounded.

Mites were separately maintained on rearing arenas composed of leaf discs of the kidney bean P. vulgaris (ca.. $2.5 \mathrm{~cm}^{2}$ ) on a wet cotton pads in a Petri dish $15 \mathrm{~cm}$. diameter in a growth chamber at a 16L-8D photo regime, $60-70 \%$ R.H. under $26 \pm 2^{\circ} \mathrm{C}$.

Crossing experiments were started similar to those of Helle and van de Bund (1962), El-Enany et al., (1988) and Sugasawa et al., (2002) as follows:

About, 12 female teliochrysalis from each mite were transferred separately, each to a new leaf disc of the above mentioned kidney beans. Adult male of the other mite was added to each female teleochrysalis from non corresponding one. The two crossing groups were Group $1((\mathrm{R} q+\hat{\mathrm{G}}))$ and Group $2\left(\left(\mathrm{G}_{+}+\mathrm{R}^{\pi}\right)\right.$. Mating was observed as soon as females molting, then males were removed from rearing discs. Mated females were kept for oviposition and discs were changed whenever necessary. Progeny of each mother female was transferred to new leaf discs separately and sexed, counted when reaching adulthood. Second set of mating experiment was carried out between 12 individuals of each brother and sisters of F1 offspring for obtaining F2 individuals. Similarly, female offspring were reared separately, counted and gender determined by reaching adulthood.

\section{RESULTS AND DISCUSSION}

Results of cross breeding experiments ( Tables 1 $\& 2$ ) showed that female fecundity of $F 1$ generation reached 88 and 95.8 eggs / $q$ for group $1((\mathrm{R} Q+$ $\delta \mathrm{G})$ ) and group 2 compared to 62.8 and 75.2 eggs / $q$ for $\mathrm{F} 2$ group 1 and 2 respectively.

Results indicated that females of F1 generation were fertile and approached the normal rate of egg production per female. Egg production obtained for females of F2 were 62.8 and 75.2 eggs per female

Table (1): Mean Number of females and males of F1 offspring obtained by cross breeding Group 1 and group 2

\begin{tabular}{lcccc}
\hline \multirow{2}{*}{ Couples } & \multicolumn{2}{c}{ Group 1 } & \multicolumn{2}{c}{ Group 2 } \\
\cline { 2 - 6 }$(\mathrm{R})$ Females & $(\mathrm{G})$ Males & $(\mathrm{G})$ Female & $(\mathrm{R})$ males \\
\hline 1 & $55(40 \mathrm{R}+15 \mathrm{~g})$ & $20(10 \mathrm{R}+10 \mathrm{G})$ & $75(60 \mathrm{G}+15 \mathrm{R})$ & $28(14 \mathrm{G}+14 \mathrm{R})$ \\
2 & $45(29 \mathrm{R}+16 \mathrm{~g})$ & $18(10 \mathrm{R}+8 \mathrm{G})$ & $64(50 \mathrm{G}+14 \mathrm{R})$ & $24(12 \mathrm{G}+12 \mathrm{R})$ \\
3 & $80(60 \mathrm{R}+20 \mathrm{~g})$ & $21(11 \mathrm{R}+11 \mathrm{G})$ & $65(55 \mathrm{G}+10 \mathrm{R})$ & $23(13 \mathrm{G}+10 \mathrm{R})$ \\
4 & $57(39 \mathrm{R}+18 \mathrm{~g})$ & $19(10 \mathrm{R}+9 \mathrm{G})$ & $67(60 \mathrm{G}+7 \mathrm{R})$ & $23(10 \mathrm{G}+13 \mathrm{R})$ \\
5 & $65(42 \mathrm{R}+23 \mathrm{~g})$ & $24(14 \mathrm{R}+10 \mathrm{G})$ & $69(56 \mathrm{G}+13 \mathrm{R})$ & $25(15 \mathrm{G}+10 \mathrm{R})$ \\
6 & $58(30 \mathrm{R}+28 \mathrm{~g})$ & $20(11 \mathrm{R}+9 \mathrm{G})$ & $65(64 \mathrm{G}+1 \mathrm{R})$ & $24(12 \mathrm{G}+12 \mathrm{R})$ \\
7 & $49(30 \mathrm{R}+19 \mathrm{~g})$ & $20(12 \mathrm{R}+8 \mathrm{G})$ & $55(40 \mathrm{G}+15 \mathrm{R})$ & $18(10 \mathrm{G}+8 \mathrm{R})$ \\
8 & $55(45 \mathrm{R}+10 \mathrm{~g})$ & $16(8 \mathrm{R}+8 \mathrm{G})$ & $99(80 \mathrm{G}+19 \mathrm{R})$ & $20(9 \mathrm{G}+11 \mathrm{R})$ \\
9 & $54(30 \mathrm{R}+24 \mathrm{~g})$ & $19(9 \mathrm{R}+10 \mathrm{G})$ & $97(87 \mathrm{G}+10 \mathrm{R})$ & $21(11 \mathrm{G}+10 \mathrm{R})$ \\
10 & $45(25 \mathrm{R}+20 \mathrm{~g})$ & $20(10 \mathrm{R}+10 \mathrm{G})$ & $73(80 \mathrm{G}+13 \mathrm{R})$ & $23(13 \mathrm{G}+10 \mathrm{R})$ \\
Total & $563(370+139)$ & $197(105+92)$ & $729(632+97)$ & $229(119+110)$ \\
\hline Mean & 56.3 & 19.7 & 72.9 & 22.9 \\
\hline Eggs / & \multicolumn{5}{c}{98} \\
\hline Sex ratio \% & \multicolumn{7}{c}{74.0} & \multicolumn{3}{c}{76.8} \\
\hline Group 1 (red females + green males) & Group 2 (green females + red males) & $\mathrm{R}=\mathrm{Red}$ & $\mathrm{G}=$ green
\end{tabular}

Table (2): Mean number of females and males produced from $F 1$ sisters and brothers mating

\begin{tabular}{|c|c|c|c|c|}
\hline \multicolumn{5}{|c|}{ No. of $\mathrm{F} 2$ females and males obtained by crossbreeding Group 1 and 2} \\
\hline \multirow{2}{*}{ Couples } & \multicolumn{2}{|c|}{ Group 1} & \multicolumn{2}{|c|}{ Group 2} \\
\hline & Females & Males & Female & Males \\
\hline 1 & 30 & 12 & 50 & 19 \\
\hline 2 & 40 & 19 & 60 & 18 \\
\hline 3 & 35 & 13 & 66 & 30 \\
\hline 4 & 50 & 15 & 56 & 25 \\
\hline 5 & 33 & 17 & 66 & 20 \\
\hline 6 & 45 & 18 & 40 & 21 \\
\hline 7 & 52 & 19 & 45 & 18 \\
\hline 8 & 61 & 22 & 50 & 22 \\
\hline 9 & 59 & 20 & 49 & 30 \\
\hline 10 & 38 & 30 & 44 & 23 \\
\hline Mean & 44.3 & 18.5 & 52.6 & 22.6 \\
\hline Eggs $/ P$ & \multicolumn{2}{|c|}{62.8} & \multicolumn{2}{|c|}{75.2} \\
\hline Sex ratio $\%$ & \multicolumn{2}{|c|}{70.1} & \multicolumn{2}{|c|}{69.9} \\
\hline
\end{tabular}


for group 1 and 2 respectively. The sex ratio obtained in F1 and F2 and recorded in Tables 1 and 2 were in conformity with normal rates, 3 times daughters as much as sons; mentioned by Wrensch (1985). Also, percentage of female color of off spring from $F 1$ and $F 2$ as shown in Tables 1 and 2 reflected high maternal effect that green females (group 2) produced more green females than red females while the opposite occurred in group 1. However, ratio between green and red females approached 5:1 in group 2 compared to nearly $2: 1$ for red to green in group 1. Males color did not vary considerably, that ratio of green and red males approached $1: 1$ in both groups 1 and 2. Similar results were mentioned by Wrensch and Murtaugh (1977) for eye color of spider mites.

Data presented herein pointed to successful interbreeding between $T$. urticae Koch and $T$. cucurbitacearum (Sayed) which follow international definition of speciation as getting fertile offspring. In other words both species are synonyms which are similar to the findings of Dupont (1979), Hinomoto et al., (2001)

\section{REFERENCES}

Attiah, H. H (1967). Revision of Tetranychus telarius complex in the U.A.R. with description of a new species (Acari: Tetranychidae) Bull. Soc. Ent. Egypte, 51:7-10

Caswell, H. and Hastings, A. (1980). Fecundity, developmental time and population growth rate: an analytical solution.Theor. Popul. Biol. 17: 71-79.

De Boer, R. (1985). Reproductive barriers. In spider mites: their biology, natural enemies and control, Vol. 1A, W. Helle and M. W. Sabelis (ed), pp.193-199. Elsevier, Amesterdam.

Dehghan, M. S.; Allahyari, Sabboori, A.; Nowzari, J. V. H. and Naveh, H. (2009). Fitness of Tetranychus urticae Koch (Acari: Tetranychidae) on different soybean cultivars: biology and fertility life-tables. Internat. J. Acarol., 35 (4): 341-347.

Dupont, L. M. (1979). One gene follow between Tetranychus urticae Koch and Tetranychus cinnabarinus (Boisdu-val) Boudreaux (Acari: Tetranychidae): synonomy between the two species. Entomol. Exp. Appl., 25: 297-303.

EL-Enany, M. A. M., Zaher, M. A. and Hassan, A.
F. (1983). Crossmating between the red spider mite Tetranychus (T.) cinnabarinus (Boisduval) and $T$. (T.) cucurbitacearum (Sayed). - Z. ang. Ent., $96: 1-3$.

EL-Enany, M.A.M., Nawar, M.S. and Zaher. M.A. (1990). On the identity of the two spotted spider mite Tetranychus urticae Koch in Egypt Acarologia, 31: 257-260.

EL-Enany, M. A. M.; Nawar, M. S. and Zaher. M. A. (1988). On the identity of the two spotted spider mite Tetranychus urticae Koch in Egypt. Bull. Zool. Soc., Egypt. , 36: 17-23.

Gotoh, T. and Tokioka. T. (1996). Genetic compatibility among diapausing red, nondiapausing red and diapausing green forms of the two-spotted spider mite, Tetranychus urticae Koch (Acari: Tetranychidae). Jpn. J. Ent 64:215225.

Helle, W. and C. F. van de Bund (1962). Crossbreeding experiments with some species of the Tetranychus urticae group. Entomol. Exp. Appl. 5: 159-165.

Hinomoto, N, Osakabe, M, Gotoh, T. and Takafuji, A. (2001). Phylogenetic analysis of green and red forms of the two-spotted spider mite, Tetranychus urticae Koch (Acari: Tetranychidae), in Japan, based on mitochondrial cytochrome oxidase subunit I sequences. Appl. Entomol. Zool .36:459-464.

Sayed, M.T. (1946). Contribution to the knowledge of Acarina of Egypt. V. Five new species of Tetranychidae. Bulletin de la Societe Entomologique Fouad Ier, 30: 79-97.

Sugasawa, J. Kitashima Y. and, Gotoh, T. (2002). Hybrid affinities between the green and the red forms of the two-spotted spider mite Tetranychus urticae (Acari: Tetranychidae) under laboratory and semi natural conditions. Appl. Entomol. Zool. 37 (1): 127-139.

Wrensch, D. L. (1985). Reproductive parameters. In spider mites: their Biology, natural enemies and control, Vol. 1A, W . Helle and M.W. sabelis (ed), pp.165-170. Elsevier, Amesterdam.

Wrensch, D. L. and Murtaugh, M. (1977). Interspecific allelism and maternal effect of eye color in spider mites. The Journal of Heredity, vol 68, 329-330.

Zaher, Gomaa, E. A. and El Enany, M.A.M. (1981). Crossbreeding between the green two spotted spider mite Tetranychus uricae Koch and T.arabicus Attiah .Z. ang.Ent.92, 527-529. 